\title{
Effects of micro-porosity and local BMP-2 administration on bioresorption of $\beta$-TCP and new bone formation
}

\author{
Atsuhito Kakuta ${ }^{1 *}$, Takaaki Tanaka ${ }^{1,2^{*}}$, Masaaki Chazono ${ }^{1,2}$, Hirokazu Komaki ${ }^{1}$, Seiichiro Kitasato ${ }^{1}$, Naoya Inagaki $^{1}$, \\ Shoshi Akiyama' and Keishi Marumo ${ }^{1}$
}

\begin{abstract}
Background: It has been reported that the microporous structure of calcium phosphate (CaP) ceramics is important to osteoconduction. Bone morphogenetic protein-2 (BMP-2) has been shown to be a promising alternative to bone grafting and a therapeutic agent promoting bone regeneration when delivered locally. The aim of this study was to evaluate the effects of micro-porosity within beta-tricalcium phosphate ( $\beta$-TCP) cylinders and local BMP-2 administration on $\beta$-TCP resorption and new bone formation.

Methods: Bilateral cylindrical bone defects were created in rabbit distal femora, and the defects were filled with $\beta$ TCP. Rabbits were divided into 3 groups; defects were filled with a $\beta$-TCP cylinder with a total of approximately $60 \%$ porosity (Group A: 13.4\% micro- and 46.9\% macropore, Group B: 38.5\% micro- and 20.3\% macropore, Group C: the same micro- and macro-porosity as in group B supplemented with BMP-2). Rabbits were sacrificed 4, 8, 12, and 24 weeks postoperatively.

Results: The number of TRAP-positive cells and new bone formation in group B were significantly greater than those in group $A$ at every period. The amount of residual $\beta$-TCP in group $C$ was less than that in group $B$ at all time periods, resulting in significantly more new bone formation in group $C$ at 8 and 12 weeks. The number of TRAPpositive cells in group $\mathrm{C}$ was maximum at 4 weeks.

Conclusions: These results suggest that the amount of submicron microporous structure and local BMP-2 administration accelerated both osteoclastic resorption of $\beta$-TCP and new bone formation, probably through a coupling-like phenomenon between resorption and new bone formation.
\end{abstract}

Keywords: Beta-tricalcium phosphate ( $\beta$-TCP), Microporous structure, Bone morphogenetic protein (BMP), Bone formation, Osteoclasts

\section{Background}

Beta-tricalcium phosphate ( $\beta$-TCP) is a calcium phosphate $(\mathrm{CaP})$ ceramic used in bone grafting as an alternative bone substitute to autograft. It has been reported that $\beta$-TCP has excellent osteoconduction and resorbability when filling a bone defect [1-7]. The $\beta$-TCP block with $75 \%$ porosity that we have used can be resorbed within a few years. However, it has a compressive strength of only $3 \mathrm{MPa}$, which is inadequate for weight-

\footnotetext{
* Correspondence: kakuta@jikei.ac.jp; tanaka.takaaki.vh@mail.hosp.go.jp ${ }^{1}$ Department of Orthopaedic Surgery, Jikei University School of Medicine, 3-25-8 Nishi-shinbashi, Minato-ku, Tokyo 105-0003, Japan

Full list of author information is available at the end of the article
}

bearing sites until bone incorporation occurs. Thus, we have developed a $\beta$-TCP block with $60 \%$ porosity. It has a compressive strength of $22 \mathrm{MPa}$, which is approximately seven-fold greater than that of $\beta$-TCP with $75 \%$ porosity. However, resorption of the $\beta$-TCP block with $60 \%$ porosity is relatively slow [8]. Thus, stimulation using a better microporous structure and/or growth factors is necessary to facilitate $\beta$-TCP resorption and new bone formation.

It has been reported that the microporous structure of $\mathrm{CaP}$ ceramics is important to osteoconduction [9-16]. The presence of micropores, by which the specific surface area of the materials is increased, seems to be

(c) The Author(s). 2019 Open Access This article is distributed under the terms of the Creative Commons Attribution 4.0 International License (http://creativecommons.org/licenses/by/4.0/), which permits unrestricted use, distribution, and 
essential for osteoconduction [17]. It was reported that $\mathrm{CaP}$ ceramics without micropores were not resorbed and there was slower bone ingrowth compared with those that had micropores [18].

Bone morphogenetic protein-2 (BMP-2) has been shown to be a promising alternative to bone grafting and a therapeutic agent promoting bone regeneration when delivered locally [19-21]. Porous CaP ceramics have been used as carriers of BMPs and have been shown to induce bone formation [22-29]. BMPs strongly induce the recruitment and differentiation of mesenchymal progenitor cells into mature osteoblasts, thereby producing a bony matrix [30]. BMPs also directly or indirectly stimulate the differentiation of osteoclast progenitor cells and promote the function of mature osteoclasts [31-34].

The aim of this study was to evaluate the effects of micro-porosity within $\beta$-TCP cylinders and local BMP-2 administration on $\beta$-TCP resorption and new bone formation.

\section{Methods \\ $\beta$-TCP}

Two types of porous $\beta$-TCP cylinders were synthesized with a mechanochemical method and provided by Olympus Terumo Biomaterials Co. (Tokyo, Japan). Briefly, $\mathrm{CaHPO}_{4} 2 \mathrm{H}_{2} \mathrm{O}$ and $\mathrm{CaCO}_{3}$ at a molar ratio of 2:1 were mixed into a slurry with pure water and zirconia ball in a pot mill for $24 \mathrm{~h}$ and dried at $80^{\circ} \mathrm{C}$. The calcium-deficient hydroxyapatite was converted to $\beta$-TCP by calcinations at $800^{\circ} \mathrm{C}$ for the cylinder with $13.4 \%$ micropore, and $900^{\circ} \mathrm{C}$ for the cylinder with $38.5 \%$ micropore. Following the preparation of a foaming slurry of $\beta$-TCP with a foaming agent and a drying process, the preforming porous body of $\beta$-TCP was obtained. After the preforming body was sintered at $1050^{\circ} \mathrm{C}$ for $1 \mathrm{~h}$, a porous $\beta$-TCP cylinder with approximately $60 \%$ porosity (38.5\% micro- and $20.3 \%$ macropore) was obtained. A second type of $\beta$-TCP cylinder with approximately $60 \%$ porosity ( $13.4 \%$ micro- and $46.9 \%$ macropore) was obtained after sintering for $10 \mathrm{~h}$. The pore size of microand macropores, pore distribution, and surface area were measured using a mercury porosimeter. Pores less than $10 \mu \mathrm{m}$ in diameter were classified as micropores; pores $\geq 10 \mu \mathrm{m}$ in diameter were classified as macropores [35]. The volumes of micro- and macropore were calculated from the area ratio on the scanning electronic micrographs $(\times 50)$.

\section{BMP-2}

BMP-2 was purchased from Osteopharma Inc. (Osaka, Japan). It was Recombinant Human BMP-2 (E.coli derived). Lyophilized BMP-2 was diluted to a concentration of $5 \mu \mathrm{g} / \mu \mathrm{l}$ by adding distilled water just before implantation.

\section{Surgical procedure}

Ninety-six New Zealand White rabbits, weighing 3.1$3.3 \mathrm{~kg}$ were used for the experiments. Rabbits were divided into the following 3 groups.

Group A ( $n=8 /$ time period) - defects were filled with $\beta$-TCP cylinder with approximately $60 \%$ porosity $(60.3 \%$ total porosity; $13.4 \%$ micro- and $46.9 \%$ macropore).

Group B ( $n=8 /$ time period) - defects were filled with $\beta$-TCP cylinder with approximately $60 \%$ porosity $(58.8 \%$ total porosity; $38.5 \%$ micro- and $20.3 \%$ macropore).

Group C ( $n=8 /$ time period) - defects were filled with $\beta$-TCP cylinder with the same micro- and macro-porosity as in group B, but supplemented with $12.5 \mu \mathrm{g}$ BMP-2.

The difference between groups A and B was the number of micropores (Fig. 1), and that between groups $\mathrm{B}$ and $\mathrm{C}$ was with or without BMP-2 administration.

Under intramuscular droperidol $(0.25 \mathrm{mg} / \mathrm{kg})$, intravenous pentobarbital $(20 \mathrm{mg} / \mathrm{kg})$ and general isoflurane $(2 \%)$ anesthesia, bilateral cylindrical bone defects $(4.1 \mathrm{~mm} \mathrm{~W} \times$ $11 \mathrm{~mm} \mathrm{~L}$ ) were created by drilling $1 \mathrm{~mm}$ anterior to the insertion of the lateral collateral ligament in the lateral aspect of the distal femur. After flushing the defects with sterile physiological saline, the hemorrhage was controlled by packing sterile gauze and the bone cavities were immediately filled with $\beta$-TCP cylinders $(4.0 \mathrm{~mm} \mathrm{~W} \times 10 \mathrm{~mm} \mathrm{~L})$. The muscle attachment was repaired and the fascia and skin were closed in layers. After surgery, all animals were allowed to move freely in their cages without joint immobilization. Rabbits were sacrificed 4, 8, 12, and 24 weeks postoperatively, and the distal part of the femur was removed and fixed with $4 \%$ paraformaldehyde in phosphate-buffered saline. After decalcification in $0.4 \mathrm{M}$ ethylenediaminetetraacetic acid for 2 weeks, serial histological sections were cut to include the deepest part of the patellar groove. Decalcified sections were obtained for hematoxylineosin and tartrate-resistant acid phosphatase (TRAP) staining. The surface area of newly formed bone and the remaining $\beta$-TCP was measured using an image analyzer (WinROOF, Mitani Co., Tokyo, Japan) and was expressed as a percentage of the defect (Fig. 2). Residual $\beta$-TCP and the number of TRAP-positive cells within the defects were measured to determine $\beta$-TCP resorption, whereas new bone formation was evaluated to analyze osteoconductivity.

The care and use of the animals in this study were in accordance with the guidelines of the Laboratory Animal Facilities of The Jikei University School of Medicine.

\section{Statistical analysis}

Data were expressed as the mean \pm SD. Student's t-tests were used for pairwise comparisons with group $B$, for example, between groups $\mathrm{A}$ and $\mathrm{B}$ or groups $\mathrm{B}$ and $\mathrm{C}$, for each time period separately. A $p$-value below 0.05 was considered statistically significant. The statistical analysis of the remaining amount of $\beta$-TCP between 

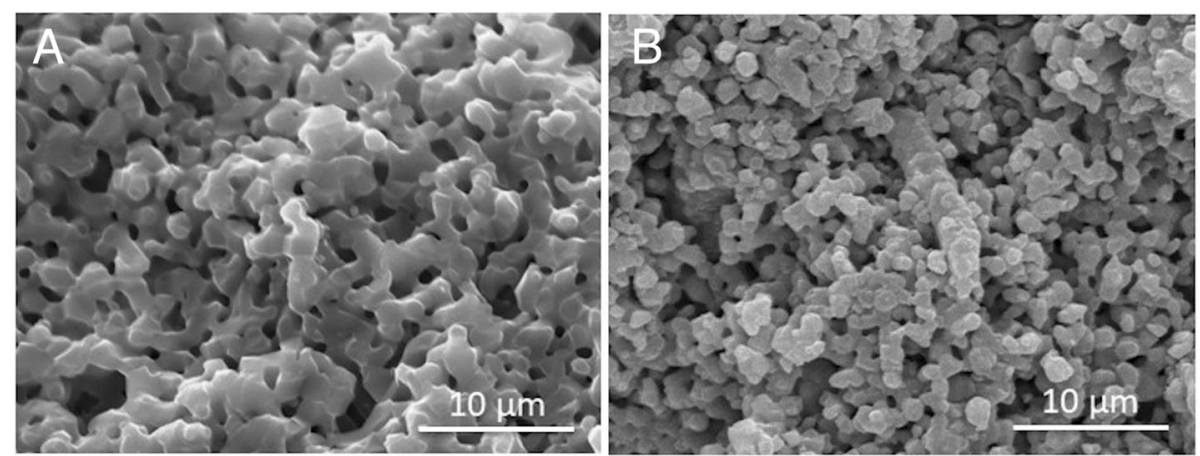

Fig. 1 Two types of $\beta$-TCP. Scanning electron micrographs (original magnification, $\times 3000$ ) of the two types of $\beta$-TCP cylinders with a total of approximately $60 \%$ porosity. $13.4 \%$ micro- and $46.9 \%$ macropore (A), 38.5\% micro- and $20.3 \%$ macropore (B). The white scale bar shows $10 \mu \mathrm{m}$

groups A and B was not performed because it was technically difficult to detect micro-pore spaces by light microscopy.

\section{Results}

\section{Micro-porosity}

The micropore diameter of the $\beta$-TCP block in group A (13.4\% micro- and $46.9 \%$ macropore) ranged from 0.4 to $0.8 \mu \mathrm{m}$ and that in groups B and C $(38.5 \%$ micro- and $20.3 \%$ macropore) ranged from 0.7 to $1.1 \mu \mathrm{m}$. Most of the micropore diameter in groups $\mathrm{B}$ and $\mathrm{C}$ were submicron.

\section{Surface area}

The surface area of the $\beta$-TCP block in group A was $0.967 \mathrm{~m}^{2} / \mathrm{g}$ and that in groups $\mathrm{B}$ and $\mathrm{C}$ was $1.802 \mathrm{~m}^{2} / \mathrm{g}$.

\section{Histological characteristics}

Histological examination showed that new bone formation was found in $\beta$-TCP cylinders in all groups at every period. However, $\beta$-TCP resorption, new bone formation, and number of TRAP-positive cells were different among the 3 groups.
TRAP-positive cells were in contact with the surface of $\beta$-TCP cylinders in all groups at 4 weeks, but the number of TRAP-positive cells in group A was smaller than that in groups B and C at 4 weeks (Fig. 3). $\beta$-TCP resorption and new bone formation occurred at the periphery of the $\beta$-TCP cylinders at 4 weeks in all groups and progressed toward the center of the $\beta$-TCP cylinders in a time dependent manner in all groups.

New bone formation was found in $\beta$-TCP cylinders of all groups by 12 weeks, but the new bone in group $\mathrm{A}$ was thinner than that in group B, whereas that in group $C$ was thicker than that in group $B$, assessed qualitatively (Fig. 4).

After 24 weeks, new bone formation was found in the center of the $\beta$-TCP cylinders and the amount of new bone was greater than that at 4 weeks in all groups. Most of the $\beta$-TCP in group $C$ was resorbed.

\section{Comparison of group A with B}

The mean amount of residual $\beta$-TCP in group $A$ at 4,8 , 12 , and 24 weeks was $37.9,30.4,24.3$, and $20.3 \%$, whereas that in group B was 35.1, 26.3, 18.6, and 12.2\%, respectively (Fig. 5). The residual amount of $\beta$-TCP in group A was greater than that in group $\mathrm{B}$ at every

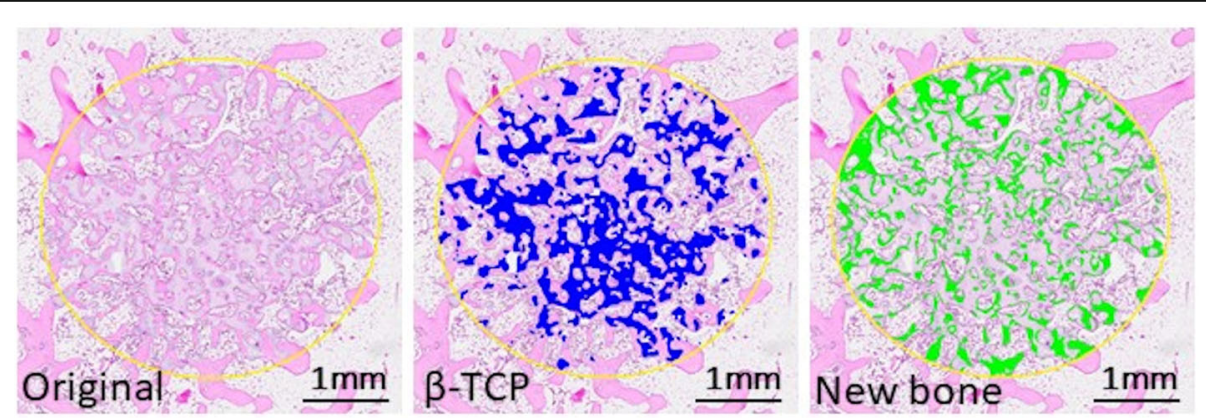

Fig. 2 An image analysis of a bone defect. The surface area of newly formed bone and the remaining $\beta$-TCP was measured using an image analyzer, (WinROOF, Mitani Co., Tokyo, Japan). The colored area was used for evaluation of the residual amount of $\beta$-TCP (blue) and newly formed bone (green) in the defect. The scale bar shows $1 \mathrm{~mm}$ 


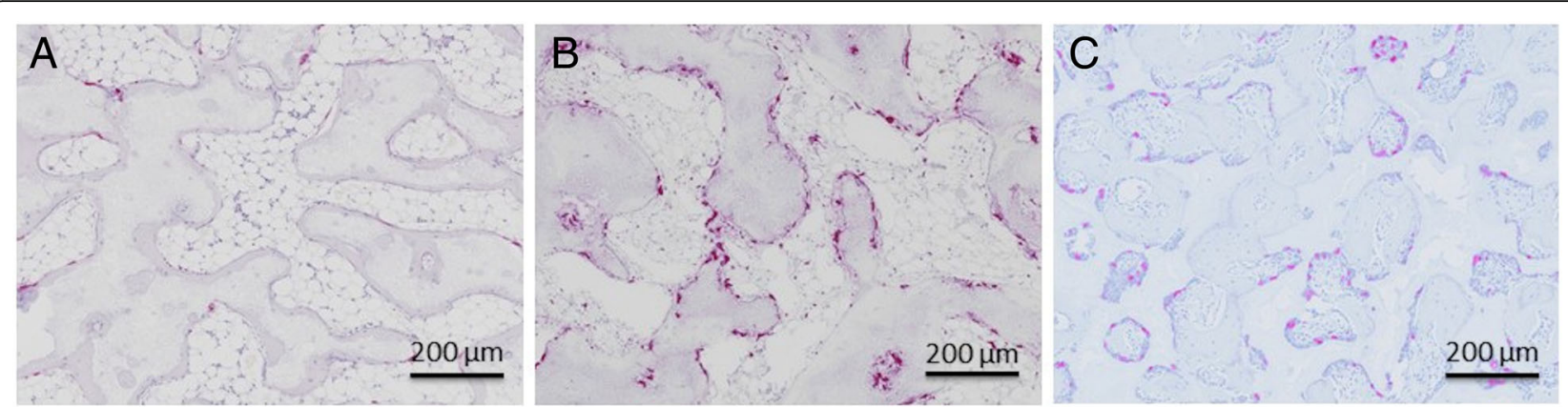

Fig. 3 Decalcified histological sections stained with TRAP 4 weeks after implantation of $\beta$-TCP cylinders (original magnification, $\times 100$ ). A, B, and $\mathbf{C}$ indicate $\beta$-TCP cylinders in group (A, B and $\mathbf{C}$ ), respectively. TRAP-positive cells were in contact with the surface of the $\beta$-TCP cylinders in all groups at 4 weeks, but the number of TRAP-positive cells in group $\mathbf{A}$ was significantly smaller than that in groups (B and $\mathbf{C})$. The scale bar shows $200 \mu \mathrm{m}$

period, but statistical significance could not be demonstrated because of the technical difficulties in detecting micro-pore spaces by light microscopy. The mean number of TRAP-positive cells in group A at 4, 8, 12, and 24 weeks was 87.8, 49.1, 29.4, and 9.4, whereas that in group B was 333.8, 256.8, 103.2, and 39.4, respectively (Fig. 6). The mean number of TRAP-positive cells in group A was significantly smaller than that in group $\mathrm{B}$ at every period. The mean amount of new bone formation in group A at 4, 8, 12, and 24 weeks was 8.4, 11.1, 12.4, and $13.9 \%$, whereas that in group B was 12.1, 13.1, 15.9, and $19.2 \%$, respectively (Fig. 7). New bone formation in group A was significantly less than that in group B at every period.

\section{Comparison of group B with C}

The mean amount of residual $\beta$-TCP in group $C$ at 4,8 , 12 , and 24 weeks was $29.9,19.1,10.3$, and $4.3 \%$, respectively (Fig. 5). The residual amount of $\beta$-TCP in group $C$ was significantly less than that in group $B$ at every period. The residual amount of $\beta$-TCP in group B was $12.2 \%$ at 24 weeks, whereas most of the $\beta$-TCP in group
C was resorbed by 24 weeks. The mean number of TRAP-positive cells in group C at 4, 8, 12, and 24 weeks was $486.9,132.5,10.6$, and 3.3, respectively (Fig. 6). The mean number of TRAP-positive cells in group $C$ reached a maximum and was larger than that in group $B$ at 4 weeks, but significantly smaller than that in group B at 8,12 , and 24 weeks. The mean new bone formation in group $C$ at $4,8,12$, and 24 weeks was 13.6, 15.9, 18.9, and $20.3 \%$, respectively (Fig. 7). New bone formation in group $\mathrm{C}$ was greater than that in group $\mathrm{B}$ at every period. However, statistical significance was found only at 8 and 12 weeks.

\section{Discussion}

\section{Material resorption}

De Groot suggested that the rate of degradation was determined by implant micro-porosity [36]. Macroporous materials without micro-porosity allow only bone ingrowth, whereas dense materials without pores of either type showed little degradation [37].

In the present study, the amount of micropores in group A was approximately $1 / 3$ of that in group $\mathrm{B}$.

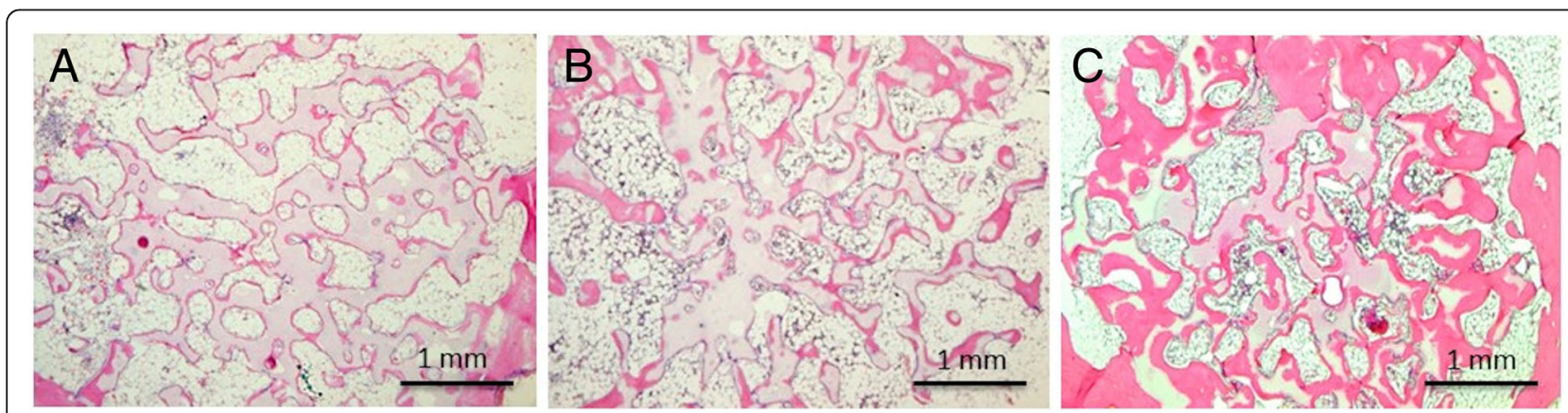

Fig. 4 Decalcified histological sections stained with hematoxylin-eosin 12 weeks after implantation of $\beta$-TCP cylinders (original magnification, $x$ 40). A, B, and $\mathbf{C}$ indicate $\beta$-TCP cylinders in group $\mathbf{A}, \mathbf{B}$, and $\mathbf{C}$, respectively. New bone formation was found in $\beta$-TCP cylinders of all groups at 12 weeks. The new bone in group $\mathbf{A}$ was thinner than that in group $\mathbf{B}$, and that in group $\mathbf{C}$ was thicker than that in group $\mathbf{B}$, assessed qualitatively. The scale bar shows $1 \mathrm{~mm}$ 


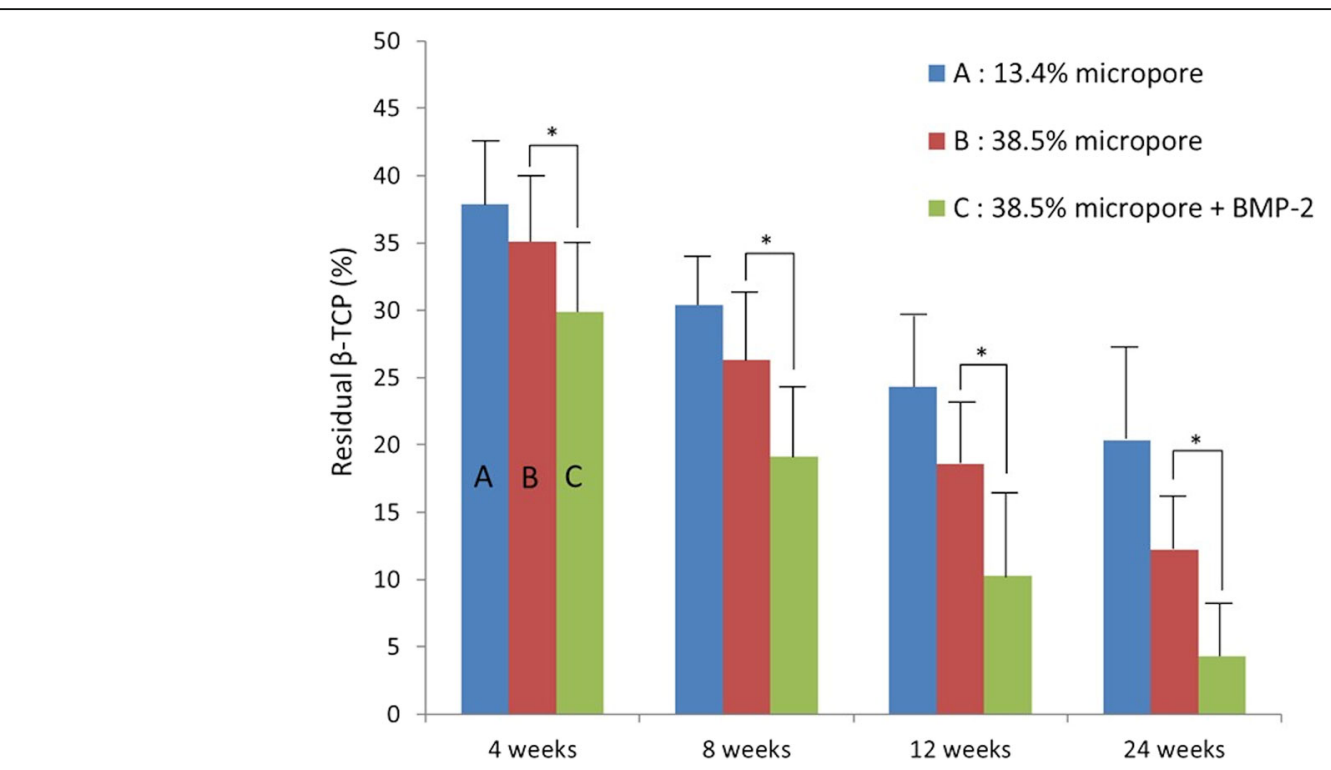

Fig. 5 Residual $\beta$-TCP. The residual amount of $\beta$-TCP in group A was greater than that in group B at every period, but statistical significance could not be demonstrated. The residual amount of $\beta$-TCP in group $C$ was significantly lower at every period compared to that in group $\mathrm{B}\left({ }^{*} p<0.05\right)$

Despite the similarity in total porosity in groups A and $\mathrm{B}, \beta$-TCP resorption was very different. The mean amount of residual $\beta$-TCP in group $A$ and that in group $B$ at 4 weeks was almost equal. Resorption of $\beta$-TCP in both groups occurred in a time dependent manner through 24 weeks. However, the mean amount of residual $\beta$-TCP in group B was less than that in group $\mathrm{A}$ at 24 weeks.

$\beta$-TCP resorption is thought to involve both solutionand cell-mediated disintegration. In our previous animal experiments, we have found numerous multinucleated giant cells on the surface of the $\beta$-TCP; most of these

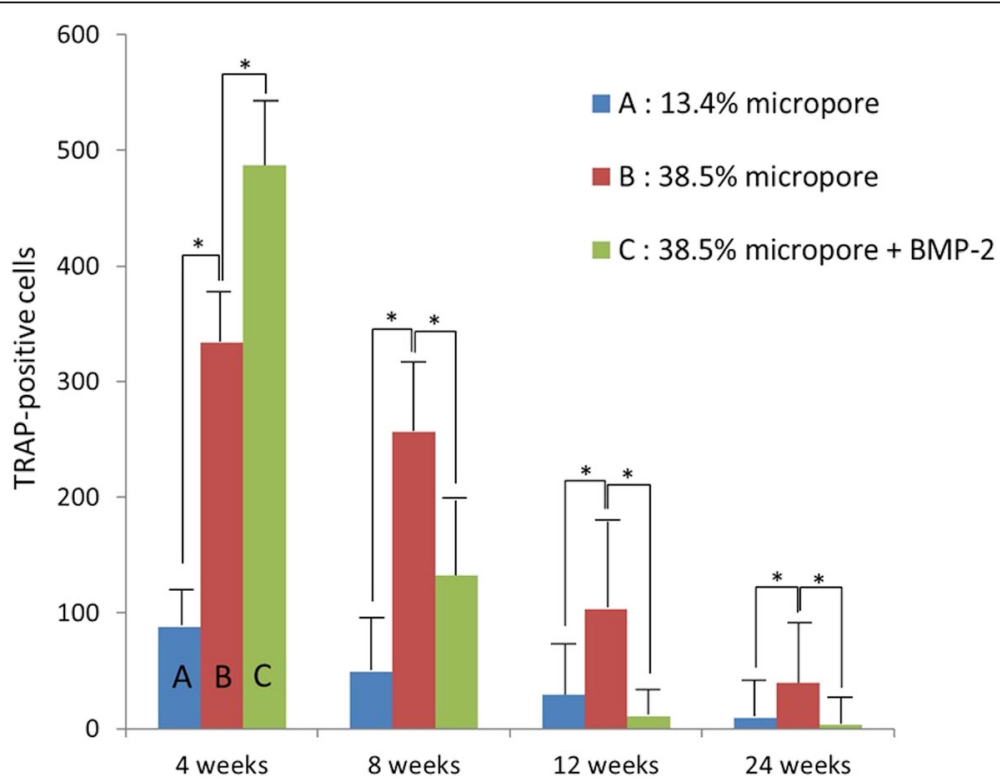

Fig. 6 TRAP-positive cells. The mean number of TRAP-positive cells in group A was significantly smaller than that in group B at every period. The mean number of TRAP-positive cells in group $C$ was larger than that in group B at 4 weeks, but smaller than that in group B at 8,12 , and 24 weeks $\left({ }^{*} p<0.05\right)$ 


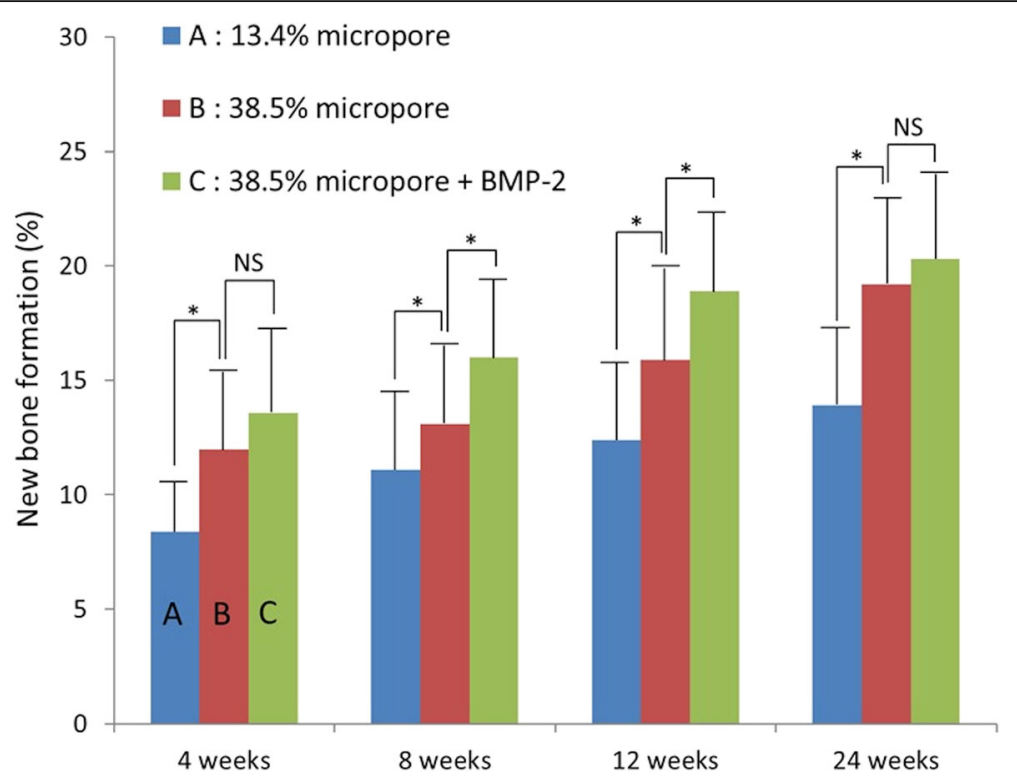

Fig. $7 \mathrm{New}$ bone formation. New bone formation in group A was significantly less than that in group B at every period. The new bone formation in group $C$ was significantly greater than that in group B at 8 and 12 weeks $\left({ }^{*} p<0.05\right)$. NS (not significant)

cells were positively stained for TRAP [4]. In the present study, both the number of TRAP positive cells and the residual amount of $\beta$-TCP in groups $\mathrm{A}$ and $\mathrm{B}$ decreased in a time dependent manner. However, the number of TRAP positive cells in group B was significantly higher than that in group A at every period, likely responsible for the lower amount of residual $\beta$ TCP in group B through 24 weeks. Thus, it is hypothesized that the number of TRAP positive cells resulting in $\beta$-TCP resorption is affected by the amount of micro-porosity.

Recently, Davison reported that in vitro, the submicron-scale surface structure of TCPs promoted osteoclast-like cell activity, fusion, and secretion of factors that amplified osteogenic differentiation of human mesenchymal stem cells when compared to micron-scale topography. Their in vivo study also showed that TCPs possessing submicron grains, pores, and roughness promoted extensive osteoclastlike cell colonization and considerable ectopic bone formation. Multinucleated osteoclast-like cells (OCLC) were observed on a submicron-scale in TCP material, but there were no OCLC on a micron-scale in TCP material [38]. In the present study, most of the micropore diameters of the $\beta$-TCP used in all groups were submicron. Our previous electron microscopic studies showed that multinucleated giant cells were in contact with the surface of $\beta$-TCP at an early stage following implantation of $\beta$-TCP. Some of them had a ruffled border at the cell-substrate interface, characteristic of osteoclasts [39].
These findings indicate that a microporous structure could provide a better microenvironment for osteoclasts, resulting in acceleration of resorption of $\beta$-TCP.

\section{New bone formation}

Some argue that micropore connection size is a critical factor with small connection sizes resulting in lower rates of bone formation [40]. Others report that the microstructure increases surface roughness, which, in turn, increases attachment, proliferation and cell differentiation [10, 41]. In the present study, new bone formation in group B was significantly greater than that in group A at every period. Furthermore, new bone in group B assessed qualitatively was thicker than that in group A.

Davison reported that in vivo, the submicron-scale surface structure of TCPs induced greater bone formation in the free implant space whereas micron-scale TCPs did not form bone in any of the subjects [38]. Many studies have shown that the specific surface area of the scaffold can be enhanced by increasing micro-porosity, thereby providing more protein adsorption sites (e.g. BMPs) [42-46]. Osteoinductive proteins can subsequently stimulate the osteogenic-related functions of cells, such as attachment, proliferation, osteogenic differentiation and biomineralization. Our previous studies showed that most of the collagen fibrils were located within micropores at an early stage following implantation of $\beta$-TCP [39]. These findings suggest that micropores may provide an environment for collagen formation, leading to the deposition of apatite crystals. 
In the present study, new bone formation was found on the periphery of $\beta$-TCP cylinders at 4 weeks and proceeded toward the center by 24 weeks through increased cell invasion and blood flow from the periphery. In our previous study using $\beta$-TCP cylinders with $75 \%$ porosity, new bone formation peaked at 4 weeks and decreased thereafter [4]. In contrast, in the present study using $60 \%$ porosity $\beta$-TCP cylinders, new bone formation increased monotonically through 24 weeks. The difference in the peak time for new bone formation between cylinders with $75 \%$ or $60 \%$ porosity may be correlated to the residual amount of $\beta$-TCP and the number of TRAP positive cells. Most $\beta$-TCP cylinders with $75 \%$ porosity was resorbed and replaced by bone by 12 weeks. In contrast, $12.2 \%$ of the $\beta$-TCP with $60 \%$ porosity in group B still remained even 24 weeks after implantation. These findings indicate that the micropores could facilitate $\beta$-TCP resorption and new bone formation. In the context of bone remodeling, osteoclasts contribute to bone formation to communicate with osteoblasts in a crosstalk that regulates the local recruitment and bone forming activity of osteoblasts. Thus, osteoclastmediated resorption may play an important role in bone formation in the $\beta$-TCP implanted area.

\section{BMP-2 administration}

The residual amount of $\beta$-TCP in group $C$ was significantly less than that in group $\mathrm{B}$ at every period and decreased in a time dependent manner in both groups. However, the number of TRAP-positive cells in group C was significantly larger than that in group B at 4 weeks, but significantly smaller than that in group B at 8,12 , and 24 weeks. Few TRAP-positive cells were found in group C at 12 and 24 weeks. BMPs not only induced bone formation, but also stimulated osteoclastogenesis and more rapid bone resorption [47-49]. Thus, the fact that the number of TRAP-positive cells in group B was larger than that in group $\mathrm{C}$ at 8 weeks and thereafter occurred because the bone resorptive effects of BMP-2 were accelerated at an early stage. New bone formation in group $C$ was greater than that in group $B$ at every period, and significantly greater at 8 and 12 weeks. These results suggest that BMP- 2 accelerated $\beta$-TCP resorption and replacement by bone in the presence of submicron micropores. Our previous clinical studies showed that approximately $1 / 3$ of the $\beta$-TCP block with $60 \%$ porosity remained 6 years after performing opening high tibial osteotomy (HTO) [50]. The $\beta$-TCP cylinders with $60 \%$ porosity used in the present study were very similar to those in clinical use. Thus, the present study may allow safer and earlier weight-bearing in patients after opening HTO.

\section{Conclusion}

Three $\beta$-TCP cylinders with different micro-porosities or with BMP-2 administration were compared in terms of material resorption and new bone formation using rabbit cancellous bone defects over 24 weeks. The results showed that more submicron microporous structure facilitated osteoclastic resorption of $\beta$-TCP and new bone formation. In addition, local BMP- 2 administration further accelerated both osteoclastic resorption of $\beta$-TCP and new bone formation. A combination of $\beta$-TCP with superior microstructure and local BMP-2 administration could accelerate bone reconstruction.

\section{Abbreviations}

BMP-2: Bone morphogenetic protein-2; CaP: Calcium phosphate; HTO: High tibial osteotomy; OCLC: Osteoclast-like cells; TRAP: Tartrate-resistant acid phosphatase; $\beta$-TCP: Beta-tricalcium phosphate

\section{Acknowledgements}

The authors gratefully thank Dr. H. Inoue, Dr. K. Takami (Olympus Terumo Biomaterials Co.), and Dr. H. Irie (Osteopharma Inc.) for technical advices.

\section{Authors' contributions}

$\Pi$ T, MC, and HK designed the experiments. AK, SK, NI, and SA performed the experiments. AK analyzed the data and drafted the manuscript. TT and KM helped to draft the manuscript. All authors read and approved the final manuscript.

Funding

Not applicable.

Availability of data and materials

All data generated or analyzed in this study are included in this published article.

Ethics approval and consent to participate

Jikei University School of Medicine Institutional Animal Care and Use Committee approved this experiment protocol (No. 2015-045).

Consent for publication

All authors have consented to the submission of this manuscript for publication.

Competing interests

All $\beta$-TCP cylinders used in the present study were provided by Olympus Terumo Biomaterials Co.

\section{Author details}

${ }^{1}$ Department of Orthopaedic Surgery, Jikei University School of Medicine, 3-25-8 Nishi-shinbashi, Minato-ku, Tokyo 105-0003, Japan. ${ }^{2}$ Department of Orthopaedic Surgery, NHO Utsunomiya National Hospital, 2160

Shimo-Okamoto, Utsunomiya City, Tochigi 329-1193, Japan.

Received: 15 May 2019 Accepted: 17 July 2019

Published online: 26 July 2019

\section{References}

1. Ohura K, Bohner M, Hardouin P, Lemaitre J, Pasquier G, Flautre B. Resorption of and bone formation from, new beta-tricalcium phosphate-monocalcium phosphate ceramics. J Biomed Mater Res. 1996;30:193-200.

2. Dong J, Uemura T, Shirasaki Y, Tateishi T. Promotion of bone formation using highly pure porous beta-TCP combined with bone marrow-derived osteogenitor cells. Biomaterials. 2002;23:4493-502.

3. Ogose A, Hotta T, Hatano H, Kawashima H, Tokunaga K, Endo N, Umezu H. Histological examination of beta-tricalcium phosphate graft in human femur. J Biomed Mater Res. 2002;63:601-4. 
4. Chazono M, Tanaka T, Komaki H, Fujii K. Bone formation and bioresorption after implantation of injectable beta-tricalcium phosphate granules-hyaluronate complex in rabbit bone defects. J Biomed Mater Res A. 2004;70:542-9.

5. Komaki H, Tanaka T, Chazono M, Kikuchi T. Repair of segmental bone defects in rabbit tibiae using a complex of beta-tricalcium phosphate, type I collagen, and fibroblast growth factor-2. Biomaterials. 2006;27:5118-26.

6. Walsh WR, Vizesi F, Michael D, Auld J, Langdown A, Oliver R, Yu Y, Irie H, Bruce W. $\beta$-TCP bone graft substitutes in a bilateral rabbit tibial defect model. Biomaterials. 2008;29:266-71.

7. Tanaka T, Komaki H, Chazono M, Kitasato S, Kakuta A, Akiyama S, Marumo K. Basic research and clinical application of beta-tricalcium phosphate ( $\beta$-TCP). Morphologie. 2017;101:164-72.

8. Tanaka T, Kumagae Y, Saito M, Chazono M, Komaki H, Kikuchi T, Kitasato S, Marumo K. Bone formation and resorption in patients after implantation of beta-tricalcium phosphate blocks with 60and 75\%porosity in opening wedge high tibial osteotomy. J Biomed Mater Res B. 2008;86:453-9.

9. Klein $\mathrm{CP}$, de Groot K, Driessen AA, van der Lubbe HB. Interaction of biodegradable beta-whitlockite ceramics with bone tissue: an in vivo study. Biomaterials. 1985:6:189-92.

10. Yuan H, Kurashina K, de Bruijn JD, Li Y, de Groot K, Zhang X. A preliminary study on osteoinduction of two kinds of calcium phosphate ceramics. Biomaterials. 1999;20:1799-806.

11. Bignon A, Chouteau J, Chevalier J, Fantozzi G, Carret J-P, Chavassieux P, Boivin G, Melin M, Hartmann D. Effect of micro- and macroporosity of bone substitutes on their mechanical properties and cellular response. J Mater Sci Mater Med. 2003;14:1089-97.

12. Hing KA, Annaz B, Saeed S, Revell PA, Buckland T. Microporosity enhances bioactivity of synthetic bone graft substitutes. J Mater Sci Mater Med. 2005;16: 467-75.

13. Habibovic P, Yuan H, van der Valk CM, Meijer G, BlitterswijkCA V, de Groot K. 3D microenvironment as essential element for osteoinduction by biomaterials. Biomaterials. 2005;26:3565-75.

14. Woodard JR, Hilldore AJ, Lan SK, Park CJ, Morgan AW, Eurell JA, Clark SG, Wheeler MB, Jamison RD, Wagoner Johnson AJ. The mechanical properties and osteoconductivity of hydroxyapatite bone scaffolds with multi-scale porosity. Biomaterials. 2007;28:45-54.

15. Chan O, Coathup MJ, Nesbitt A, Ho CY, Hing KA, Buckland T, Campion C, Blunn GW. The effects of microporosity on osteoinduction of calcium phosphate bone graft substitute biomaterials. Acta Biomater. 2012;8:2788-94.

16. Zhang J, Barbieri D, ten Hoopen $H$, de Bruijn JD, van Bitterswijk CA, Yuan $H$. Microporous calcium phosphate ceramics driving osteogenesis through surface architecture. J Biomed Mater Res A. 2015;103:1188-99.

17. Habibovic $P$, Sees TM, van den Doel MA, van Blitterswijk CA, de Groot $K$. Osteoinduction by biomaterials-physicochemical and structural influences. J Biomed Mater Res A. 2006;77:747-62.

18. Yamasaki N, Hirao M, Nanno K, Sugiyasu K, Tamai N, Hashimoto N, Yoshikawa H, Myoui A. A comparative assessment of synthetic ceramic bone substitutes with different composition and microstructure in rabbit femoral condyle model. J Biomed Mater Res B. 2009;91:788-98.

19. Reddi AH. Bone morphogenetic proteins: from basic science to clinical applications. J Bone Joint Surg Am. 2001:83:1-6.

20. Einhorn TA. Clinical applications of recombinant human BMPs: early experience and future development. J Bone Joint Surg Am. 2003;85:82-8.

21. Bessa PC, Casal M, Reis RL. Bone morphogenetic proteins in tissue engineering: the road from laboratory to clinic, part II (BMP delivery). J Tissue Eng Regen Med. 2008;2:81-96.

22. Laffargue $P$, Hildebrand $H F$, Rtaimate $M$, Frayssinet $P$, Amoureux JP, Marchandise X. Evaluation of human recombinant bone morphogenetic protein-2-loaded tricalcium phosphate implants in rabbits' bone defects. Bone. 1999;25:55-8.

23. Yuan H, De Bruijn JD, Zhang X, Van Blitterswijk CA, De Groot K. Use of an osteoinductive biomaterial as a bone morphogenetic protein carrier. J Mater Sci Mater Med. 2001;12:761-6.

24. Li RH, Bouxsein ML, Blake CA, D’Augusta D, Kim H, Li XJ, Wozney JM, Seeherman HJ. rhBMP-2 injected in a calcium phosphate paste (alpha-BSM) accelerates healing in the rabbit ulnar osteotomy model. J Orthop Res. 2003;21:997-1004

25. Edwards RB 3rd, Seeherman HJ, Bogdanske JJ, Devitt J, Vanderby R Jr, Markel MD. Percutaneous injection of recombinant human bone morphogenetic protein-2 in a calcium phosphate paste accelerates healing of a canine tibial osteotomy. J Bone Joint Surg Am. 2004;86:1425-38.
26. Seeherman HJ, Bouxsein M, Kim H, Li R, Li XJ, Aiolova M, Wozney JM. Recombinant human bone morphogenetic protein-2 delivered in an injectable calcium phosphate paste accelerates osteotomy-site healing in a nonhuman primate model. J Bone Joint Surg Am. 2004;86:1961-72.

27. Seeherman HJ, Azari K, Bidic S, Rogers L, Li XJ, Hollinger JO, Wozney JM. rhBMP-2 delivered in a calcium phosphate cement accelerates bridging of criticalsized defects in rabbit radii. J Bone Joint Surg Am. 2006;88:1553-65.

28. Perrier M, Lu Y, Nemke B, Kobayashi H, Peterson A, Markel M. Acceleration of second and fourth metatarsal fracture healing with recombinant human bone morphogenetic protein-2/calcium phosphate cement in horses. Vet Surg. 2008;37:648-55.

29. Bai B, Yin Z, Xu Q, Lew M, Chen Y, Ye J, Wu J, Chen D, Zeng Y. Histological changes of an injectable rhBMP-2/calcium phosphate cement in vertebroplasty of rhesus monkey. Spine. 2009;34:1887-92.

30. Urist MR, Nilsson O, Rasmussen J, Hirota W, Lovell T, Schmalzreid T, Finerman GA. Bone regeneration under the influence of a bone morphogenetic protein (BMP) beta tricalcium phosphate (TCP) composite in skull trephine defects in dogs. Clin Orthop Relat Res. 1987;214:295-304.

31. Kanatani $M$, Sugimoto $T$, Kaji $H$, Kobayashi T, Nishiyama K, Fukase M, Kumegawa M, Chihara K. Stimulatory effect of bone morphogenetic protein-2 on osteoclast-like cell formation and bone-resorbing activity. J Bone Miner Res. 1995;10:1681-90.

32. Kaneko H, Arakawa T, Mano H, Kaneda T, Ogasawara A, Nakagawa M, Toyama Y, Yabe Y, Kumegawa M, Hakeda Y. Direct stimulation of osteoclastic bone resorption by bone morphogenetic protein (BMP)-2 and expression of BMP receptors in mature osteoclasts. Bone. 2000;27:479-86.

33. Itoh K, Udagawa N, Katagiri T, lemura S, Ueno N, Yasuda H, Higashio K, Quinn JM, Gillespie MT, Martin TJ, Suda T, Takahashi N. Bone morphogenetic protein 2 stimulates osteoclast differentiation and survival supported by receptor activator of nuclear factor-kappa B ligand. Endocrinology. 2001;142:3656-62.

34. Okamoto M, Murai J, Yoshikawa H, Tsumaki N. Bone morphogenetic proteins in bone stimulate osteoclasts and osteoblasts during bone development. J Bone Miner Res. 2006;21:1022-33.

35. Implants for surgery -Calcium phosphates- part3: Hydroxyapatite and betatricalcium phosphate bone substitutes. ISO13175-3:2012.

36. de Groot K. Bioceramics consisting of calcium phosphate salts. Biomaterials. 1980;1:47-50

37. Kotani S, Fujita Y, Kitsugi T, Nakamura T, Yamamuro T, Ohtsuki C, Kokubo T. Bone bonding mechanism of beta-tricalcium phosphate. J Biomed Mater Res. 1991;25:1303-15.

38. Davison NL, Luo X, Schoenmaker T, Everts V, Yuan H, Barrère-de Groot F, de Bruijn JD. Submicron-scale surface architecture of tricalcium phosphate directs osteogenesis in vitro and in vivo. Eur Cell Mater. 2014;27:281-97.

39. Chazono M, Tanaka T, Kitasato S, Kikuchi T, Marumo K. Electron microscopic study on bone formation and bioresorption after implantation of betatricalcium phosphate in rabbit models. J Orthop Sci. 2008;13:550-5.

40. Hing KA, Best SM, Tanner KE, Bonfield W, Revell PA. Mediation of bone ingrowth in porous hydroxyapatite bone graft substitutes. J Biomed Mater Res A. 2004;68:187-200.

41. Karageorgiou V, Kaplan D. Scaffolds and osteogenesis. Biomaterials. 2005;27: 5474-91.

42. De Groot J. Carriers that concentrate native bone morphogenetic protein in vivo. Tissue Eng. 1998;4:337-41.

43. Rouahi M, Gallet O, Champion E, Dentzer J, Hardouin P, Anselme K. Influence of hydroxyapatite microstructure on human bone cell response. J Biomed Mater Res A. 2006;78:222-35.

44. Li XM, van Blitterswijk CA, Feng QL, Cui F, Watari F. The effect of calcium phosphate microstructure on bone-related cells in vitro. Biomaterials. 2008; 29:3306-16.

45. Zhu XD, Fan HS, Xiao YM, Li DX, Zhang HJ, Luxbacher T, Zhang XD. Effect of surface structure on protein adsorption to biphasic calcium-phosphate ceramics in vitro and in vivo. Acta Biomater. 2009:5:1311-8.

46. Perez RA. Mestres G2. Role of pore size and morphology in musculo-skeletal tissue regeneration. Mater Sci Eng C. 2016;61:922-39.

47. Pradhan BB, Bae HW, Dawson EG, Patel W, Delamarter RB. Graft resorption with the use of bone morphogenetic protein: lessons from anterior lumbar interbody fusion using femoral ring allografts and recombinant human bone morphogenetic protein-2. Spine. 2006;31:277-84.

48. Toth JM, Boden SD, Burkus JK, Badura JM, Peckham SM, McKay WF. Shortterm osteoclastic activity induced by locally high concentrations of 
recombinant human bone morphogenetic protein-2 in a cancellous bone environment. Spine. 2009;34:539-50.

49. Seeherman HJ, Li XJ, Bouxsein ML, Wozney JM. rhBMP-2 induces transient bone resorption followed by bone formation in a nonhuman primate coredefect model. J Bone Joint Surg Am. 2010;92:411-26.

50. Tanaka T, Kumagae Y, Chazono M, Kitasato S, Kakuta A, Marumo K. A novel evaluation system to monitor bone formation and $\beta$-tricalcium phosphate resorption in opening wedge high tibial osteotomy. Knee Surg Sports Traumatol Arthrosc. 2015;23:2007-11.

\section{Publisher's Note}

Springer Nature remains neutral with regard to jurisdictional claims in published maps and institutional affiliations.

Ready to submit your research? Choose BMC and benefit from:

- fast, convenient online submission

- thorough peer review by experienced researchers in your field

- rapid publication on acceptance

- support for research data, including large and complex data types

- gold Open Access which fosters wider collaboration and increased citations

- maximum visibility for your research: over $100 \mathrm{M}$ website views per year

At $\mathrm{BMC}$, research is always in progress.

Learn more biomedcentral.com/submissions 